\begin{abstract}
Iranica
Abstracta Iranica Revue bibliographique pour le domaine irano-aryen

Volume 37-38-39 | 2018

Comptes rendus des publications de 2014-2016
\end{abstract}

\title{
Flavia Ruani (éd.). Les controverses religieuses en syriaque
}

\section{Christelle Jullien}

\section{(2) OpenEdition}

1 Journals

\section{Édition électronique}

URL : http://journals.openedition.org/abstractairanica/44266

DOI : 10.4000/abstractairanica.44266

ISBN : 1961-960X

ISSN : 1961-960X

Éditeur :

CNRS (UMR 7528 Mondes iraniens et indiens), Éditions de l'IFRI

Référence électronique

Christelle Jullien, « Flavia Ruani (éd.). Les controverses religieuses en syriaque », Abstracta Iranica [En ligne], Volume 37-38-39 | 2018, document 12, mis en ligne le 30 décembre 2018, consulté le 29 septembre 2020. URL : http://journals.openedition.org/abstractairanica/44266 ; DOI : https://doi.org/ 10.4000/abstractairanica.44266

Ce document a été généré automatiquement le 29 septembre 2020

Tous droits réservés 


\title{
Flavia Ruani (éd.). Les controverses religieuses en syriaque
}

\author{
Christelle Jullien
}

\section{RÉFÉRENCE}

Flavia Ruani (éd.). Les controverses religieuses en syriaque. Paris : Geuthner, 2016, 456 p., (Études syriaques 13), ISBN 978-2-7053-3961-6.

1 Cet ouvrage est le résultat de la table-ronde annuelle de la Société d'études syriaques organisée à Paris en 2015, augmentée de quelques contributions. Plusieurs articles intéressent plus particulièrement les controverses qui ont marqué profondément l'histoire interne des différentes communautés syriaques en territoire iranien.

2 Ces articles, listés ci-dessous, font chacun l'objet d'une recension séparée dans ce même numéro.

3 - Sebastian P. Brock, «Les controverses christologiques en syriaque : controverses réelles et controverses imaginées »

4 - Florence Jullien, «Les controverses entre chrétiens en milieu sassanide : un enjeu identitaire »

5 - Richard Payne, «Les polémiques syro-orientales contre le zoroastrisme et leurs contextes politiques»

6 - John W. Watt, «Pensée grecque, controverses syriaques »

7 - Barbara Roggema, « Pour une lecture des dialogues islamo-chrétiens en syriaque à la lumière des controverses internes à l'islam » 


\section{AUTEURS}

\section{CHRISTELLE JULLIEN}

CNRS, Mondes iranien et indien, Paris 